\section{Trygt kjøp for helsepersonell og blivende mødre}

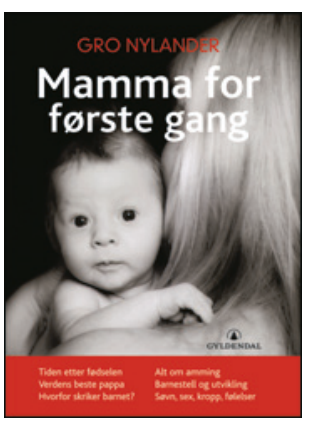

Gro Nylander

Mamma for første gang

4. utg. 312 s, ill. Oslo: Gyldendal, 2016.

Pris NOK 379

ISBN 978-82-05-49801-3

Denne boken har veiledet nybakte mødre og helsepersonell i 17 år i mange land. Nå foreligger den i ny, revidert utgave. Tidligere utgaver har fått meget god omtale. Gro Nylander, gynekolog og obstetriker ved Oslo universitetssykehus og fortsatt aktiv ved Nasjonalt kompetansesenter for amming, øser av sin store erfaring med veiledning av helsepersonell og blivende mødre. Boken er ment mest for hun som venter barn og snart skal oppleve å føde, bli mor og ta hånd om den lille verdensborgeren de første seks månedene.

Boken er i solid paperback. Den er rikt illustrert med sort-hvitt bilder. Strektegninger illustrerer praktiske råd. Bakerst i hvert kapittel er det sjekkliste eller oppsummeringer. Bakerst i boken er det en referanseliste for hvert kapittel. Det angis også generell litteratur og nyttige nettadresser. Stikkordregisteret gjør det mulig å bruke boken som oppslagsbok.

Denne boken kan leses fra perm til perm. Her er opplevelsene til Kari, Charlotte og Linda. Vi får også høre om pappaene Are, Fredrik og Kristian. Men Gro Nylander gir klar beskjed at mammaene fremdeles er viktigst i det 21. århundre, $i$ alle fall den første tiden etter fødselen. For nå skal ammingen på plass, selv om det kan koste mye strev. Og akkurat her er boken nyttig fordi den gir personlig veiledning for alle mulige vanskeligheter som kan møte mor i samspillet med barnet.

Boken er inndelt i 24 kapitler - som barnets første kontakt med mors brystknopp (for det er ikke noen vorte!), hva pappa kan hjelpe til med, problemene etter operative inngrep, barseltiden, morsmelk som mat og medisin, vanlige ammeproblemer, smokk, mating med flaske, barnets utvikling, skrik og slitsomme netter, samliv og prevensjon, og sykdommer og plager hos barnet frem til seks måneders alder.

Rådene gjøres virkelighetsnære ved bruk av kasuistikker. Men av og til kan det se ut som enkeltopplevelsene alene danner grunnlag for rådene. Bruk av metoklopramid for å fremme amming kan diskuteres. (Metoklopramid øker nivået av prolaktin i serum og kan derfor føre til økt melkeproduksjon.) Boken gir sparsommelig informasjon om flaskeernæring, kanskje fordi grenseoppgangen mellom informasjon og reklame er uskarp. Og denne boken har et klart budskap: Morsmelk er best!

Kjære helsepersonell og blivende mamma; dette er en bok som fortsatt er aktuell og et trygt kjøp.

Per Lagerløv

Professor i allmennmedisin, Universitetet i Oslo

\section{Kortfattet innføring i anestesiologi}

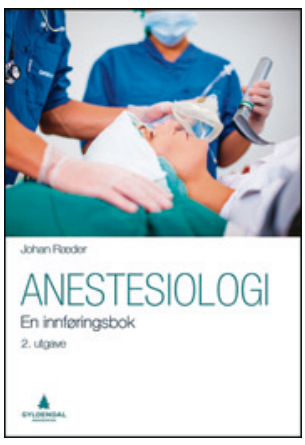

Johan Ræder

Anestesiologi

En innføringsbok. 2. utg. 254 s, tab, ill. Oslo:

Gyldendal Akademisk, 2016. Pris NOK 469

ISBN 978-82-05-49472-5
Denne norske boken henvender seg til legestudenter, sykepleiere og annet helsepersonell. Den vil også være nyttig som oppslagsbok og kortfattet lærebok for sykepleiere på sengepost, for leger som skal henvise pasienter til operasjon, og for de som tar imot pasienter etter operasjon. Boken, som er i paperback, utkom første gang i 2009. Denne 2. utgaven er fullstendig revidert og utvidet blant annet med flere nye kapitler.

Det er en krevende oppgave å dekke et så stort fagområde på 254 sider. Moderne anestesi er et omfattende fagfelt som spenner over flere medisinske spesialiteter. Anestesiologien har utviklet seg fra ren anestesihåndtering til også å omfatte intensivmedisin, akuttmedisin og smertebehandling. Boken er inndelt i nettopp disse fire temaene og har i tillegg en femte del om etiske spørsmål. Delene utfyller hverandre og gir et helhetlig bilde av faget. De enkelte kapitlene er fyldige nok og kan godt leses og forstås hver for seg. Det er hensiktsmessig for en innføringsbok. Men det er ikke til å unngå at kapitlene til dels overlapper hverandre, og gjentagelser forekommer.

Kapitlene er systematisk oppbygd, og innholdet presenteres i et godt, klart og muntlig språk. Det gjør boken er lettlest. Selv et tungt kapittel som farmakologi er praktisk rettet og gir grei forklaring på de farmakologiske begrepene som er nødvendig for forståelsen av moderne anestesiologisk legemiddelbruk. Boken har også med det siste om automatiserte og computerstyrte infusjonspumper som i dag brukes i total intravenøs anestesi. Overvåking av vitale parametre under anestesi og intensivmedisin har utviklet seg fra respiratorisk og hemodynamisk overvåking. I prinsipp kan hver enkelt medikamentvirkning overvåkes. Alle data som samles skal dokumenteres og journalføres. I dag er dette automatisert gjennom elektroniske anestesijournaler. Høyteknologiske anestesi og overvåking er gitt god plass i alle avsnitt av boken.

Intensivmedisin presenteres på 36 sider i en presis, kortfattet og forståelig fortellerstil. Særlig verdifullt er valg av gode eksempler på klinisk forløp av pasientkasus. Dette er et godt pedagogisk grep som er svært vellykket og illustrerer kompliserte medisinske problemstillinger som en anestesilege kan møte og må løse i samarbeid på tvers av spesialiteter. Det er dette som gjør moderne anestesiologi og intensivmedisin til et utfordrende og spennende fag. Boken er illustrert med flere gode tabeller, figurer og skjemaer. Med dagens muligheter for god fotografering kunne bildene av anestesi- og overvåkingsutstyr vært av vesentlig bedre kvalitet.

Utgivelsen av denne norskspråklige innføringsboken i moderne anestesiologi er i seg selv enestående og hilses velkommen. Jeg tror boken så avgjort vil være nyttig, og at den vil nå den målgruppen den er tiltenkt.

Sidsel Hetland

Anestesilege, Oslo 